\title{
HAKIKAT SANKSI ADAT SANGASKARA DANDA \\ TERHADAP PELANGGARAN ADAT GAMIA GAMANA
}

\author{
Oleh: \\ Ida Bagus Sudarma Putra*
}

\begin{abstract}
Community life in Bali is inseparable from the customs inherent in the life of society itself. Religion and culture become a crucial factor to implement the order of indigenous people. Social change has an impact on the life of indigenous people. Many custom cases that occur, one of them is having sexual relation / marriage with close relatives called Gamia Gamana. Sanctions toward this custom offense generally carry out by cleaning up the village or prayascita village. The purpose of this ceremony is to restore the sanctity and balance of the village; therefore, it becomes pure again. This sanction is given as a fine to the person who does custom offense called Sangaskara Danda.

The research questions of this study can be formulated as follows; how is the nature of Sangaskara Danda? And how is the implementation of Sangaskara Danda sanction toward customs offenses Gamia Gamana? The method used in this study was an empirical law derived from primary data and secondary data. The nature of this study was descriptive, with qualitative data analysis. Overall results of these analyses were presented in the description which described the complete problem under study along with a critical discussion.

The nature of custom sanction Sangaskara Danda can be seen from the form of sanction, the purpose of the sanction, and the implementation of the sanction. The sanction Sangaskara Danda is in the form of Prayascita Sangaskara Danda and Matirta Gamana (for Hindu Priest). The purpose of this sanction is restoring the cosmic balance (sekala-niskala); moreover, cleansing and purifying themselves, their family and village environment. The implementation of these sanctions is done by imposing the perpetrator of custom offenses either in material or immaterial. Similarly, in implementing sanction Sangaskara Danda toward custom offenses Gamia Gamana is to continue to implement Sangaskara Danda in the form of Prayascita Desa and impose other sanction such as not allowed joining as the member of the village, pay fines, bathed in the sea or even "diaben" (symbolically).
\end{abstract}

Keywords : Sangaskara Danda, Gamia Gemana

\section{PENDAHULUAN}

\section{Latar Belakang}

Masyarakat adat di Bali tumbuh dan berkembang disertai dengan ajaran agama dan budaya yang melekat dalam setiap kehidupannya. dalam mengatur kehidupan

Mahasiswa Magister Ilmu Hukum Unud masyarakat adatnya, diperlukan aturanaturan yang bersumber dari nilai-nilai religius (keagamaan) yang tersusun dalam suatu aturan hukum yang disebut hukum adat. Hal ini disebabkan karena antara agama dan hukum adat adalah merupakan rangkaian yang saling berkaitan dan tidak terpisahkan satu dengan lainnya. 
Keterikatan agama khususnya agama Hindu dengan Hukum Adat di Bali dapat ditemukan pada cara menyelesaikan suatu pelanggaran adatnya (delik adat) yang selalu disertai dengan cara melaksanakan upakara/ ritual kegamaan. Demikian pula dengan tata cara penjatuhan sanksi adat terhadap delik adat pada umumnya hanya berupa pelaksanaan kewajiban yang dilandasi oleh ajaran agama dan nilai filosofis dengan tujuan menetralisir kehidupan masyarakat adatnya dari keadaan yang disebut dengan leteh (kotor). ${ }^{1}$

Impelmentasi sanksi adat di Bali pada umumnya disertai dengan upacara pelukatan dan pembersihan yang disebut dengan pamarisudhan atau Maprayascitta. Upacara Pamarisudhan atau Maprayascitta merupakan bentuk upacara adat di Bali yang memiliki fungsi untuk menetralisir atau membersihkan masyarakat dan wilayah tempat terjadinya suatu peristiwa atau pelangaran adat. Sanksi adat ini bukan merupakan suatu penyiksaan atau derita, namun tujuannya sebagai penetralisir kembalinya kehidupan masyarakat yang seimbang. ${ }^{2}$

Sanksi pada hakikatnya adalah reaksi hukum atas perbuatan warga masyarakat yang tidak seharusnya. delik adat sebagian besar diatur dalam aturan-aturan (awigawig) desa yang bersangkutan. Pelanggaran terhadap aturan tersebut, dikenakan sanksi adat berupa denda (danda).

I Gusti Ketut Ariawan 1992, "Eksistensi Delik Hukum Adat Bali Dalam Rangka Pembentukan Hukum Pidana Nasional", Tesis, Program Pascasarjana Program Studi Ilmu Hukum, Jakarta, hlm.10.

2 I Made Widnyana, 1992, Delik Adat Dalam Pembangunan, Orasi Pengukuhan Guru Besar, Fakultas Hukum Universitas Udayana, Denpasar, hlm.11.
Sanksi adat dalam hukum adat Bali dapat digolongkan menjadi 3 (tiga) yang dikenal dengan Tri Danda yakni :

\section{Arta Danda}

adalah golongan sanksi adat dalam bentuk materi yaitu dengan cara membayar uang atau penggantian harta benda (benda-benda materiil).

\section{Sangaskara Danda}

Yaitu sanksi berupa pelaksanaan upacara tertentu untuk mengembalikan keseimbangan magis dan dilakukan sesuai dengan ajaran agama Hindu).

3. Jiwa Danda

Yaitu golongan sanksi berupa penderitaan jasmani dan atau rohani/ jiwa. Seperti Mengaksama, mapilaku, lumaku, mengolas-olas, nyuaka (minta maaf).

Denda (danda) diberikan kepada masyarakat adat/krama yang melakukan pelanggaran adat (delik adat). Pelanggaran adat atau yang dikenal dengan Delik adat merupakan suatu perilaku yang melanggar aturan-aturan yang berlaku di masyarakat yang dapat mengganggu dan merusak tata kehidupan masyarakat baik secara material maupun inmaterial terhadap individunya maupun masyarakat sebagai kesatuannya ${ }^{3}$

Delik adat adalah segala perbuatan atau kejadian yang bertentangan dengan kepatuhan, kerukunan, ketertiban, keamanan, rasa keadilan, dan kesadaran masyarakat yang bersangkutan. ${ }^{4}$

Suardana, 2007, "Delik dan Sanksi Adat Dalam Perspektif Hukum Nasional", dalam Sudantra, \& Parwata, Oka, Editor, Wicara Lan Pamidanda, Udayana University Press, Denpasar, hlm.75.

Hilman Hadikusuman, 1961, Hukum Pidana Adat, CV Rajawali, Jakarta, hlm.307 
Adapun jenis-jenis delik adat yang masih hidup dalam hukum adat Bali, dapat diklasifikasikan sebagai berikut :

a. Delik adat yang menyangkut kesusilaan, contohnya lokika sangraha (persetubuhan atas dasar cinta antara laki-laki dan perempuan yang samasama masih bujang), drati krama (berzina), Gamia Gamana (hubungan seksual antara orang-orang yang berhubungan darah sangat dekat), dan salah krama (berhubungan kelamin dengan binatang).

b. Delik adat yang menyangkut harta benda, contohnya pencurian benda suci, merusak benda suci, dan lainlain.

c. Delik adat yang melanggar kepentingan pribadi, seperti mamisuh (mencaci), mapisuna (memfitnah), dan lain-lain.

d. Delik adat karena kelalaian atau tidak menjalankan kewajiban, seperti tidak melaksanakan kewajiban sebagai krama desa yang berupa ayahan (kewajiban melakukan pekerjaan untuk desa) atau papeson (urunan berupa barang). ${ }^{5}$

Dalam prakteknya, Pelanggaran hukum yang terjadi dapat berupa pelanggaran terhadap hukum adat (awig-awig, pararem, kebiasaan-kebiasaan, dresta) maupun pelanggaran-pelanggaran terhadap hukum negara. Pelanggaran terhadap norma-norma hukum adat secara teoritis dapat disebut sebagai delik adat. $^{6}$ Dengan demikian, delik adat berkaitan erat dengan semua perbuatan atau kejadian yang bertentangan dengan kepatutan, kerukunan, ketertiban, keamanan, rasa keadilan dan kesadaran hukum masyarakat bersangkutan.

Dengan perkembangan jaman dan perubahan sosial yang cukup pesat, membawa manusia hidup dalam kemajuan terutama kemajuan teknologi yang tinggi. Hal ini tentunya membawa pengaruh pola hidup dan perilaku di masyarakat. perubahan sosial ini juga membuat etika dan moral manusia menjadi tidak sejalan dengan pola kehidupan masyarakat adat yang tunduk dengan aturan adat baik berupa awig-awig maupun aturan lainnya.

Semakin banyaknya delik adat yang terjadimembuatBali menjadi tidak seimbang. Banyak kasus yang terjadi yang digolongkan sebagai delik adat, diantaranya delik adat Gamia Gamana. Ada beberapa kasus yang pernah terjadi di Bali yang termasuk ke dalam delik adat gamaia gamana yaitu kasus yang terjadi di Klungkung yakni seorang ayah melakukan hubungan seksual dengan anak kandungnya sampai melahirkan anak, kejadian tersbut bahkan dilakukan dihadapan istrinya. Kasus lainnya juga terjadi di tabanan yakni dua orang gadis kakak adik disetubuhi oleh ayah kandung dan kakeknya.

Beranjak dari kasus delik adat yang terjadi di Bali inilah membuat penulis tertarik membuat jurnal dengan judul Hakikat Sanksi Adat Sangaskara Danda Terhadap Delik Adat Gamia Gamana. 


\section{Rumusan Masalah}

Dari latar belakang di atas, maka dapat ditarik suatu Rumusan Masalah yaitu :

1. Bagaimanakah Hakikat Sanksi Sangaskara Danda?

2. Bagaimanakah Penerapan Sanksi Sangaskara Danda Terhadap Delik Adat Gamia Gemana?

\section{Tujuan Penelitian}

Penelitian ini pada umumnya memiliki tujuan mengetahui Hakikat Sanksi Sangaskara Danda Terhadap Delik Adat Gamia Gemana.

Tujuan khusus penelitian ini adalah untuk:

1. Mengetahui Hakikat Sanksi
Sangaskara Danda.

2. Mengetahui Penerapan Sanksi Sangaskara Danda Terhadap Delik Adat Gamia Gemana.

\section{METODE PENELITIAN}

Penelitian ini menggunakan metode penelitian hukum empris yang menggunakan sumber data primer dan sumber data sekunder yang bersifat deskripstip dengan analisis data kualitatif. Hasil dari analisis tersebut akan disajikan dengan cara deskripsi yaitu memaparkan permasalahan yang diteliti secara sistematis dan kritis.

\section{HASIL DAN PEMBAHASAN}

\section{Hakikat Sanksi Sangaskara Danda}

Sanksi adalah padanan dari istilah asing yaitu sanctie (Belanda), atau sanction (Inggris).

Menurut "Black's Law Dictionary" Seven Edition, Sanksi adalah A Penalty or coercive measure that result from failure to comply with a law, rule, or order (a sanction for discovery abuse.

Menurut Soetandyo Wignjosoebroto, sanksi adalah seluruh akibat hukum yang harus ditanggung oleh subyek yang didakwa melakukan suatu perbuatan hukum atau menyebabkan terjadinya suatu peristiwa hukum. ${ }^{7}$

\section{a. Bentuk Sanksi Sangaskara Danda}

Hukum adat di Bali dilandasi oleh ajaran agama Hindu yang dikenal dengan konsep Tri Hita Karana ini merupakan konsep keseimbangan kehidupan manusia yaitu keseimbangan antara manusia dengan Tuhan, manusia dengan manusia manusia dengan alam. Perbuatan melanggar terhadap aturan-aturan adat dapat mempengaruhi terganggunya keseimbangan baik secara nyata atau tidak nyata (sekala-niskala). Dengan demikian maka perlu diadakan pemulihan terhadap pelanggaran tersebut dengan memberikan pamidanda .

Salah satu pamidanda yang masih hidup dan berlaku di masyarakat yaitu Sangaskara Danda yaitu hukuman berupa pelaksanaan upacara.

Ada 2 (dua) Bentuk Sangaskara Danda, yaitu :

\section{1) Maprayascita}

Yaitu merupakan bentuk prosesi keagamaan yang bertujuan untuk menetralisir dari terjadinya ketergangguan keseimbangan wilayah bila mengalami suatu delik adat tertentu yang dapat merusak tatanan

Soetandyo Wignjosoebroto, 2008, Hukum Dalam Masyarakat, Perkembangan dan Masalah, Sebuah Pengantar ke Arah Sosiologi Hukum, Bayumedia Publishing, Malang, hlm.138. 
kehidupan secara magis pada kehidupan masyarakat dari keadaan yang kotor (leteh)

Prayascita merupakan banten (sarana) yang digunakan untuk membersihkan atau menyucikan pikiran sebelum melaksanakan upacara-upacara suci.

Dalam tradisi Hindu di Bali, Prayascita dipakai dalam upacara Yadnya dengan tujuan untuk mengembalikan alam pikiran yang kotor dan dapat diarahkan kembali menuju "citta". Pikiran yang suci dan netral itulah yang disebut dengan "citta". Jika sudah ditarik dengan dorongan hawa nafsu maka disebut "manah". Namun jika dapat membedakan baik dan buruk dalam pikiran itu disebut "wiweka". Dengan "wiweka", pikiran dapat diarahkan kembali menuju "citta"

Banten prayascita termasuk banten yang memiliki mutu kedewataan (Daiwi Sampad), oleh karena itu Banten prayascita berfungsi sebagai pebersihan dan merupakan simbul yang mengandung nilai religius.

Kata Prayascita berasal dari suku kata pra- yas dan citta yang mengandung arti penyucian segala kesedihan. Dalam kamus Jawa Kuna Indonesia Prayascitta (dalam bahasa sansekerta berarti taubat, penebusan dosa, ganti rugi) penebusan dosa, korban penebusan, upacara penyucian (menghapus dosa atau akibat kutukan).

Pikiran yang kotor dapat dikembalikan dengan pemahaman Tattwa Jnana, Susila, Agama dan Upacara Yadnya. Banten Prayascita selalu disertai dengan banten Byakala atau banten Durmangala. Prasyascita sebagai lambang penyucian rohani, Byakala sebagai lambang penyucian jasmani.
Bentuk Banten Prayascitta menyerupai atau menggambarkan bundar atau cakra buana, bahwa bumi ini bundar yang berputar mengelilingi matahari dan bulan sehingga terjadi siang dan malam yang sesuai dengan ajaran rwa bhineda. Fungsi dari Banten Prayascitta adalah sebagai pembersihan atau ngelukat Pura, Pelinggih dan Upakara dalam Upacara Yadnya tersebut. Makna yang terkandung dalam Banten Prayascitta adalah Sebagai simbul yang mengandung nilai religius sebagai kekuatan Siwa Guru.

\section{2) Matirtha Gemana}

Yaitu kewajiban/sanksi adat bagi seorang pendeta yang telah melakukan kesalahan yang disebut dengan atataji, seperti meracuni orang, merusak kehormatan orang.

Ida Pendada Gede Made Gunung menyatakan bahwa Tirtha Gemana merupakan Tirtha Yatra yang sering dilakukan umat, yaitu pergi untuk melakukan pembersihan / penyucian diri ke tempattempat suci, kemudian kembali pulang. Tirtha gemana dalam klasifikasi umum dapat dibedakan menjadi 2 yaitu Tirtha Gemana Bhuana Agung dan Tirtha Gemana Bhuana Alit. ${ }^{8}$

\section{a. Tujuan Sanksi Sangaskara Danda}

Sanksi adalah secara umum memiliki istilah dan konvensional dimana secara diarti lebih luas dan berubah-ubah karena berkonotasi dalam ruang lingkup yang lumayan luas. Sanksi bukan hanya dipergunakan dalam ruang lingkup hukum,

www.noteshindu.com, diunduh tanggal 21 September 2015 
melainkan digunakan pada ruang lingkup lainnya seperti ruang lingkup pendidikan, sosial, agama dan lain sebagainya.

Adapun tujuan dari sanksi pada umumnya untuk mengatur kehidupan manusia agar tercipta suasana yang tertib. Demikin pula Sanksi adat, yang berorientasi pada pengembalian kesucian desa dan ketertiban desa (ngewaliang kesudamalan desa lan kasukertannyane).

Adapun Tujuan dari sanksi sangaskara danda antara lain :

1) Mengembalikan kesucian desa / pura;

2) Mengembalikan keseimbangan;

3) Memberikan efek jera kepada para pelaku;

4) Membersihkan diri, desa dan pura

a. Penerapan Sanksi Sangaskara

\section{Danda}

Kehidupan masyarakat di Bali erat kaitannya dengan budaya yang memiliki nilai-nilai bersifat religuis. Demikian pula Aturan-aturan adat yang masih berkembang dan hidup di masyarakat dan diakui di masyarakat sangat kental terhadap nilainilai religius. Agama Hindu dan hukum adat di Bali adalah satu rangkian yang tidak dapat dipisahkan sebagai dampak dari peranan agama Hindu yang sedemikian kuatnya terhadap kebiasaan-kebiasaan (adat istiadat).

Masyarakat adat yang hidup dalam satu kesatuan wilayah diatur dengan aturan agar menjadi tertib. Setiap pelanggaran yang dilakukan oleh krama desa akan dikenakan sanksi.

Setiap pelanggaranadatmengakibatkan ketidakseimbangan pada masyarakat, oleh karena itu setiap pelanggaran adat harus dijatuhi sanksi yaitu berupa hukuman adat seperti membuat upakara pembersihan desa, membayar denda, atau sanksi lainnya yang kesemuanya itu berfungsi sebagai alat untuk mengembalikan kesucian dan keseimbangan desa $^{9}$.

Sanksi atau hukum atas pelanggaran bukan hanya berupa keputusan penguasa adat atau hakim, tetapi dapat pula berupa celaan, tidak diajak bicara, tidak diberi tempat dalam upacara, diusir atau dikeluarkan dari lingkungan masyarakat hukuman dan lain sebagainya. Semua sanksi tersebut merupakan suatu bentuk hukum sosial atas perbuatan anti sosial menurut ukuran adat.

Umumnya, sanksi yang sering diterapkan dalam masyarakat adat di Bali yaitu sanksi Sangaskara Danda. Sanksi ini diterapkan agar dapat mengembalikan keseimbangan dan kesucian desa setempat.

Penerapan sanksi tersebut dilakukan dengan mengadakan upacara suci keagamaan berupa upacara prayascita dan matirtha gemana. Pembersihan ini dilakukan oleh prajuru desa bersama-sama dengan krama desa. Segala bentuk biaya yang dikeluarkan untuk upacara tersebut dibebankan kepada pelaku pelanggaran. Hal ini sebagai salah satu bentuk sanksi yang harus dijalankan bila ada krama desa melakukan suatu pelanggaran adat.

Pelaku yang melakukan pelangaran adat juga harus menjalankan sanksi lainnya seperti matirtha gemana (apabila pelaku seorang pendeta / sulinggih /pemangku).

Soemadiningrat, H. R. Otje Salman, 2011, Rekonseptualisasi Hukum Adat Kontemporer, PT. Alumni, Bandung, h. 16. 
Selain sanksi Sangaskara Danda, bagi pelaku pelanggaran adat juga dikenakan sanksi berupa Jiwa Danda dan Arta Danda sesuai dengan tingkat kesalahan yang dilakukannya.

\section{Penerapan Sanksi Sangaskara Danda Terhadap Pelanggaran Gamia Gemana}

Dewasainikehidupansosialkeagamaan di Bali kian mengalami kemunduran. Hal ini disebabkan karena perkembangan dan perubahan sosial yang cukup tinggi. Perubahan sosial juga dipengaruhi oleh kemajuan teknologi. Dengan perubahan sosial dan kemajuan teknologi tersebut membawa perubahan moral dan etika dalam kehidupan manusia di masyarakat khusunya masyarakat adat.

Moral dan etika sangat menentukan kehidupan masyarakat adat di Bali. Dengan perubahan sosial, prilaku masyarakat ikut berubah. Banyak pelangaran yang terjadi akibat kemajuan teknologi yang cukup pesat. Salah satu pelanggaran yang akhir-akhir ini terjadi yaitu melakukan perkawinan/ hubungan persetubuhan antara orang-orang yang masih mempunyai hubungan darah yang dikenal dengan Gamia Gemana.

Gamia Gemana adalah delik adat berupa larangan perkawinan/ hubungan seksual antara seorang laki-laki dengan perempuan yang masih memiliki keterikatan kekeluargaan dekat secara garis keturunan lurus maupun garis keturunan kesamping ${ }^{10}$.

10 I Made Widnyana, 2013, Hukum Pidana Adat Dalam Pembaharuan Hukum Pidana, PT. Fikahati Anmeska, Jakarta, hal.216.
Perbuatan Gamia Gamana tidak saja bertentangan dengan agama hindu dan ketentuan hukum adat, melainkan juga bertentangan dengan tata nilai yang berlaku dalam masyarakat adat Bali. Perbuatan tersebut juga dapat menimbulkan kegoncangan dan bencana bagi masyarakat luas. Dengan demikian harus melakukan upacara adat berupa bersih desa/pemarisudha desa atau mecaru.

Wayan P.Windia mengatakan bahwa pelanggaran adat Gamia Gamana adalah merupakan suatu larangan perkawinan atau hubungan seksual seorang yang masih memiliki keterikatan kekeluargaan (hubungan keluarga dekat) dilihat dari garis keturunan lurus ataupun garis keturunan kesamping. Perkawinan sedarah tersebut dianggap tidak baik karena bersifat panas ${ }^{11}$.

Terhadap pelanggaran itu dapat diproses melalui upaya mekanisme peradilan pidana. Dalam penjatuhan sanksi pada hukum adat tergantung pada kepekaan atau tidaknya kesalahan yang dilakukan. Pada lazimnya dalam praktek peradilan di Bali sangatlah sedikit dijumpai tentang putusan hakim yang memberikan penjatuhan sinksi pidana sebagai pemenuhan tanggung jawab adat, tetapi dalam suduh pandang lain suatu masyarakat adat menginginkan di berikan sanksi pidana sebagai pemenuhan kewajiban adat. Pada pelanggaran-pelanggaran yang menginginkan penerapan sanksi pemenuhan kewajiban adat, hakim dalam tugasnya akan bertentangan atau berbenturan terhadap ketentuan Pasal 10 KUHP, tidak ada dijelaskan tentang pemenuhan kewajiban adat sebagai jenis pidana sebagai salah 
satunya. Pada sisi normatif, ketentuan Pasal 5 ayat (3) sub b UU No.1 Drt/ 1951 dapat memberikan peluang kepada hakim agar dapat memberikan penjatuhan sanksi adat, tetapi pada praktek tentang hal itu seperti pada yang dimaksud sangatlah minim dilaksanakan hakim.

Ketentuan dalam undang-undang tersebut menyatakan bahwa hukum pidana sipil yang sampai saat ini masih dipakai terhadap kaula-kaula wilayah-wilayah swapraja dan orang-orang yang diadili pada waktu dulu terhadap pengadilan adat, adat masih tetap digunakan bagi kaula-kaula dan orang tersebut.

Di sebagian wilayah-wilayah yang masih memberlakukan penerapan terhadap hukum pidana adat, dalam sebagian pelanggaran dalam prakteknya menginginkan berlakunya pemenuhan kewajiban adat dalam usaha pemulihan keseimbangan kehidupan masyarakatnya, bahkan pada beberapa pelanggaran adat pada sudut pandang hukum formal merupakan tidak jauh dari suatu perbuatan kriminal biasa akan tetapi dari sudut pandang kaca mata adat, dalam sebuah pelanggaran tersebut sangat sulit untuk dituntaskan atau diselesaikan secara gambling melalui sistem sistem peradilan pidana, artinya pidana yang di berikan dari hakim belum dikatakan bisa memulihkan keseimbangan hidup dalam masyarakat adat yang di timbulkan oleh adanya suatu pelanggaran yang terjadi.

Di Bali masyarakat adatnya berpandangan bahwa pelanggaran adat yang timbul tidak saja dapat merugikan atau mengganggu kehidupan secara materiil akan tetapijuga dapat merugikan secara immaterial dalam kerugian immaterial dapat di lakukan dengan jalan melakukan ritual-ritual adat yang bertujuan untuk menetralisir atau mengembalikan keseimbangan kehidupan masyarakat dari perasaan kotor (carub atau leteh),

Disisi lain dalam Undang-Undang Tentang Perkawinan Nomor 1 tahun 1974 di dalamnya juga mengatur tentang tidak bolehnya perkawinan pada orang -orang yang memiliki hubungan dekat (keluarga dekat) sebagaimana ditentukan pada Pasal 8 yaitu perkawinan dilarang antara dua orang yang :

1. berhubungan darah (seksual) dalam garis keturunan lurus keatas atau ke bawah;

2. masih ada hubungan darah pada garis keturunan kesamping yaitu dengan saudara orang tua, seorang dengan saudara neneknya;

3. berhubungan semenda, yaitu mertua, anak tiri, menantu, ibu/bapak tiri;

4. berhubungan susuan, yaitu orang susuan, anak susuan, saudara susuan, dan bibi/paman susuan;

5. berhubungan saudara dengan istri atau sebagai bibi atau kemenakan dari isri dalam hal seorang suami beristri lebih dari seorang;

6. mempunyai hubungan yang oleh agamanya atau peraturan lain yang berlaku dilarang kawin.

Dari segi ilmu kedokteran, Hubungan seksual atau perkawinan sedarah juga tidak baik karena keturunan dari perkawinan tersebut sangat berpotensi menjadi cacat 
karena faktor genetik (bila 2 gen resesif bertemu, maka cenderung akan menghasilkan keturunan yang cacat) .

Disisi lain, Gamia Gamana dapat dikatakan suatu perbuatan atau pelanggaran adatyang dapat mencemerkanataungeletehin wilayah tempat terjadinya pelanggaran tersebut, oleh karena hal tersebut dianggap perlu adanya upaya untuk menetralisir keadaan mental keluarga masyarakat, korban, pelaku, serta desa supaya kembali seimbang.

Di Bali Hukum Adat dipengaruhi oleh ajaran Agama Hindu mengembalikan keseimbangan desa harus melaksanakan upacara ritual Pembersihan desa (Prayascitta Gumi) tujuannya hendaknya supaya wilayah tempat atau desa terjadinya delik adat Gamia Gamana dapat menjadi bersih dan harmonis.

Dengan upacara ritual prayascitta gumi semua pihak diharapkan baik pelaku, keluarga masyarakat desa maupun korban tersebut menjadi sadar bahwa tindakan tersebut merupakan aib yang harus dihindari.

Jenis sanksi adat sangatlah beragam, Sangaskara Danda merupakan sanksi yang dijatuhkan terhadap para pelaku delik adat Gamia Gamana, diantaranya :

1. di pecat atau dikeluarkan dari anggota banjar;

2. di selong serta didenda;

3. simbolis seperti ditenggelamkan di laut ( pelaku di mandikan ke laut sebagai simbolis ditenggelamkan)

4. Pelaku dituntut natau diwajibkan untuk mengadakan upacara pembersihan dengan segala biaya ditanggung pelaku;

5. Pelakun pisahkan atau diceraikan (apabila sudah melakukan perkawinan gamia gaman);

6. diaben (dibakar secara simbolik).

Sanksi adat sebagaimana tersebut lebih banyak mengarah pada sanksi adat Sangaskara Danda. Hal ini disebabkan karena sanksi ini sangat relevan diterapkan dan dianggap dapat mengembalikan keadaan desa sebagaimana mestinya.

Penerapan sanksi ini umumnya dimuat dalam aturan adat setempat baik berupa awig-awig, paparem, atau aturan adat lainnya yang berlaku di wilayah tersebut.

Dari berbagai jenis sanksi yang diatur dalam aturan desa adat, Sangaskara Danda merupakan sanksi yang dianggap paling efektif untuk dilaksanakan mengingat pengaruhnya sangat besar terhadap tatanan hidup masyarakat.

Dalam masyarakat adat di Bali secara kuat sudah melembagakan pada kepercayaan atau keyakinan bahwa setiap pelanggaran yang menimbulkan terganggunya keseimbangan masyarakat yang belum diselesaikan dengan upaya-upaya ritual keagamaan maka hal tersebut dapat dikatakan sebagai suatu penyebab menderitanya keluarga masyarakat adat, maka dengan itu pelaku pelanggaran berkewajiban untuk melakukan ritual-ritual adat yang bertujuan untuk menetralisir atau mengembalikan kembali keseimbangan wilayah desa dari perasaan kotor atau (leteh)

Penerapanm sanksi Sangaskara Danda sejalan dengan Teori Sistem Hukum dari 
Lawrence M. Friedman, yakni subsatnsi hukum, struktur hukum dan budaya hukum.

Substansi adalah aturan atau norma hukum yang merupakan produk hukum. Setiap daerah harus memiliki aturan yang digunakan sebagai dasar untuk mengatur kehidupan masyarakatnya. Demikian halnya dengan Sangaskara Danda merupakan produk hukum yang umumnya tertuang dalam awig-awig/ pararem suatu daerah.

Struktur hukum merupakan unsurnyata dari hukum. sebuah kerangka permanen, atau unsur tubuh lembaga dengan berbagai fungsinya dalam rangka mendukung bekerjanya hukum tersebut. Bila dikaitkan dengan Sangaskara Danda, dalam suatu daerah juga harus ada aparat untuk dapat menerapkan produk hukum yang berlaku. Penerapan sanksi Sangaskara Danda dapat dilaksanakan bila terdapat aparat hukum.

Demikian pula dengan budaya hukum. Implementasi dari sanksi Sangaskara Danda terhadap Delik Adat Gamia Gamana sangat menentukan. Dengan budaya hukum, cara penerapan sanksi tersebut terhadap kasus yang terjadi berbeda-beda, semuanya tergantung dari budaya adat daerah masingmasing.

Selain teori sistem hukum, ajaran dari Moh.Koesno tentang Menyelesaikan dan Memutus juga dapat digunakan dalam penerapan sanksi Sangaskara Danda terhadap Delik Adat Gamia Gamana.

\section{SIMPULAN DAN SARAN}

\section{Simpulan}

Dengan berdasarkan uraian tersebut di atas, dapat ditarik suatu simpulan yaitu : a. Bahwa sanksi hakikat sanksi Sangaskara Danda dapat dilihat dari bentuk sanksinya yakni Meprayascita dan Matirtha Gamana. Tujuan dari sanksi ini adalah untuk mengembalikan kesucian dan keseimbangan desa serta masyarakat yang ada di dalamnya. Dengan demikian penerapan sanksi ini sangat harus dilaksanakan mengingat hukum adat Bali sangat erat kaitannya dengan hukum Agama Hindu.

b. Penerapan sanksi Sangasakara Danda Terhadap Delik Adat Gamia Gamana tidak ditentukan secara pasti dan sangat beragam tergantung wilayah yang bersangkutan. Namun pada umumnya penerapan sanksinya berupa prayascita dan matirtha gamana disamping sanksi lainnya seperti tidak boleh masuk anggota banjar, membayar denda, dimandikan di laut, atau bahkan diaben (secara simbolik).

\section{Saran}

Adapun saran yang dapat penulis sampaikan yakni :

a. Diharapkan agar dalam setiap delik adat harus diberikan sanksi secara tegas. Sanksi tersebut tidak hanya berupa Sangaskara Danda, namun juga mestinya diberikan sanksi pidana dengan tujuan agar memberikan efek jera terhadap para pelaku delik adat.

b. Diharapkan kepada desa untuk dapat melakukan penyuluhan lebih intensif kepada warga / krama tentang pendidikan etika dan moral. Selain itu memberikan pengetahuan dan 
pemahaman hukum dan menerapkan sanksi secara tegas apabila melanggar hukum.

\section{Daftar Pustaka}

Ariawan I Gusti Ketut, 1992. "Eksistensi

Delik Hukum Adat Bali Dalam Rangka Pembentukan Hukum Pidana Nasional", Tesis, ProgramPascasarjana Program Studi Ilmu Hukum, Jakarta.

Hadikusuman Hilman 1961, Hukum Pidana Adat, CV Rajawali, Jakarta.

Soemadiningrat, H. R. Otje Salman, 2011, Rekonseptualisasi Hukum Adat Kontemporer, PT. Alumni, Bandung. Suardana, 2007, "Delik dan Sanksi Adat Dalam Perspektif Hukum Nasional”, dalam Sudantra, \& Parwata, Oka, Editor, Wicara Lan Pamidanda, Udayana University Press, Denpasar. Widnyana, I Made, 1992, Delik Adat Dalam Pembangunan, OrasiPengukuhanGuru Besar, Fakultas Hukum Universitas Udayana, Denpasar.

Widnyana I Made, 2013, Hukum Pidana Adat

Dalam Pembaharuan Hukum Pidana, PT. Fikahati Anmeska, Jakarta.

Wignjosoebroto Soetandyo, 2008, Hukum

Dalam Masyarakat, Perkembangan dan Masalah, Sebuah Pengantar ke Arah Sosiologi Hukum, Bayumedia

Publishing, Malang.

www.noteshindu.com. diunduh tanggal 21

September 2015.

www.balisaja.com, diunduh tanggal 27

September 2015. 